\title{
Historic alleys of Podlasie region - Droblin, Leśna Podlaska commune
}

\section{Wojciech Durlak, Margot Dudkiewicz, Mariusz Szmagara}

\author{
University of Life Sciences in Lublin
}

\begin{abstract}
The article defines the historical value and presents the results of a detailed dendrological inventory of lime trees alley in Droblin, Leśna Podlaska commune. The alley is a part of the manor and park complex of the nineteenth century and it is a valuable object not only in historical, but also in natural terms. The manor house, around which grow inventoried trees, originally belonged to the Hińcza and Wężyk families and currently it serves as a private catering and hotel facility with a stable. The access alley after the restoration and complementary plantings is to be the main thoroughfare leading to the manor house.
\end{abstract}

Keywords: roadside alley, tree stand, Droblin, Leśna Podlaska commune

\section{Introduction}

Park alleys were already created in ancient times. In Persia, in times of Darius III, along the main roads there grew olive trees, in the shade of which the postal runners could relax and eat fruit growing on the trees [Lemiechow 1905-1906]. Alleys were also planted in Egypt and Rome. In Greece, however, they were not popular [Siewniak and Mitkowska 1998].

The etymology of the word 'alley' derives from the French 'allée' meaning initially garden path, then the path leading from the house to the garden, along which there were usually flower beds, sometimes trees or shrubs [Worobiec 2009]. In Europe, alley planting became popular under the influence of Marco Polo's reports from his trip to China. Andrea Palladio in the work of 1570, "Four books about architecture” advised planting of alley trees as 'they give shade, make journey pleasant and cheer up souls.'

In Central Europe, the oldest preserved alley, neither in the park nor in the garden, was set up in the years 1615-1619 in Hellbrunn near Salzburg, where 680 lime trees and oaks were planted. Only 13 lime trees survived until present times. In the eighteenth century trees were planted along access roads to manor houses and farms, along communication routes and channels. In the past alley trees were grown to protect from the sun, wind and snow.Alleys were also used for military purposes connected with moving of the army (Napoleon alleys) [Worobiec 2009]. Alleys served as landmarks and they were of utilitarian use, especially in case of massive grow of mulberry (silk farming) and fruit trees [Sikora 2010].

Borrowed from England, the idea of establishing a broad belt of trees in the 20 s of the nineteenth century was promoted by Dezydery Chłapowski. Such plantings of trees played ecological functions and increased economic effects of manor houses [Chojnacka and Wilkaniec 2007]. In the eighteenth and nineteenth centuries lime trees, chestnut and ash trees alleys marked the main access roads to the palaces and mansions. In contrast, willow and fruit trees marked the boundaries of estates. Płoski [2009] on the basis of Hübner's publications from 1914 states that alley trees next to the roads should be planted in front of a ditch, and the important part of protecting their trunks was a stone placed at the side of the road. In the main alleys next to the trees there were usually planted shrubs in the form of hedges [Siewniak and Mitkowska 1998].

Mansions of Podlasie region usually represented the classic type of the Polish manor. Manor was often extended by further alcoves, had a porch or a portico column. The overall economic and political situation of Podlasie region of the eighteenth and nineteenth centuries did not favor the development of large manor 
houses [Maroszek and Rogalewska 1994]. Droblin in Leśna Podlaska commune belonged to a group of smaller, farm manor houses.

Roadside alleys constitute an integral part of the Polish cultural landscape. Roads in addition to their transportation function also affect the aesthetic perception of the landscape. They often define the tradition of the place and constitute the indicator for identification of the area in comparison to other regions of Europe [Przesymcka and Sosnowska 2004]. The old alley trees are also the mainstay of various forms of wildlife, especially in sparsely wooded areas [Szczepanowska 2012].

The issue of preservation and maintainance of the historic alleys, respecting the principles of their conservation, is a relatively new topic. Each case requires careful evaluation, and the spectrum of activities is very wide- from the preservation of individual trees to the total renewal of the alley, which is possible only in exceptional circumstances [Krosigk et al. 2003].

\section{Material and methods}

The research included archival query on the subject and a detailed inventory of vegetation carried out in July 2012. Measurements of circuits of trunks at a height of $130 \mathrm{~cm}$ were done. The height of the trees and the coverage of crowns were measured. Trees and alley system were applied to the geodetic substratum by simple orthogonal geodetic coordinates measured by the laser range finder DISTO A5 Leica. Additionally, tree stand was located in the field by means of the positioning DAKOTA device (GPS). Approximate age of trees was determined on the basis of tree age table developed by Majdecki [1980-1986].

A documentary form of the alley was adopted with some modifications made by Kubus [2010]. The contents consist of the following items: geographical and administrative location of alleys, cadastral data; characteristics of the alley as a foundation - a type of the alley, its length and width; the number of trees, their characteristics (taxon, the basic dimensions and age of trees; assessment of the conservation status; compositional and spatial analysis of the alley as a work of gardening art; historical analysis of the alley and attachments (drawings of the alley, photographic documentation).

The final document was submitted to the Voivodeship Conservator of Monuments in Biała Podlaska. Soon there will be undertaken some works to supplement the planting and maintenance of old trees.

\section{Results}

Documentary data of lime trees alley in Droblin

\section{Geographical and administrative location of alleys, cadastral data}

Location of the property on the maps - geographical latitude and longitude in degrees:

- N $52^{\circ} 08^{\prime} 8.24^{\prime \prime}$

- E $22^{\circ} 58^{\prime} 44.31^{\prime \prime}$

Droblin is located $30 \mathrm{~km}$ north-west of Biała Podlaska in Lublin voivodeship. A manor complex (manor house, park and alley) is included in the register of monuments NID A/133. The Klukówka river, one of the tributaries of the Krzna river, flows through the village. In medieval historical sources it is said that Droblin already existed in the fourteenth century. It was then owned by the Mazurian nobility. In the park surrounding the manor house there grow old trees, including lime, chestnut and ash trees. The front part of the manor house faces the south-west, and the building is built on a rectangular plan. The owner of the manor house and the park is a private person. The alley belongs to Leśna Podlaska commune.

In the natural structure of the municipality there should be distinguished relatively low proportion of forests and woodlots - 15.3\% (with an average forest cover of Lublin voivodeship $21.87 \%$ ) and a high percentage of surface waters. The municipality is not a varied area, for the most part it is flat, with poorly developed valley network. This region is one of the coldest areas of Lublin voivodeship. Continental climate dominates here, which is expressed by a large span of extreme temperatures and not a very high rainfall. Among many trees 
of the park in Droblin one of them (Fraxinus excelsior L. $440 \mathrm{~cm}$ diameter and $20 \mathrm{~m}$ height) is one of the most valuable monuments of nature in Leśna Podlaska commune.

\section{Characteristics of the alley as the manor - park complex}

Double row alley is located at a dirt road, which is a historical connection to the manor house. Alley width is $5 \mathrm{~m}$ and length $-220 \mathrm{~m}$

\section{Characteristics of trees}

A detailed dendrological inventory was made in 2012. In the alley there were inventoried a total of 35 positions, including 25 trees and 10 shrub groups belonging to the class Angiospermae.

- Populus nigra L., black poplar - 23 specimens, the most valuable items have circuits 435,420 and $415 \mathrm{~cm}$ and a height of $15 \mathrm{~m}$.

- Pyrus pyraster Burgsd., common pear -2 specimens in the form of a shrub occupying an area of $9 \mathrm{~m}^{2}$.

There were inventoried 7 groups of Caragana arborescens Lam. in the form of hedges, 1 specimen of Ligustrum vulgare L. and two groups of Syringa vulgaris L.

Approximate age of poplars is estimated to be about 150 years. In a much later period, probably carrageenan plantings were designed to emphasise and embellish the alley.

During the inventory work the value of trees in the plot was defined. Valuation of the trees in the alley was done using the method developed by H. Szczepanowska (2009), which, through the evaluation of the condition of the plants will help in the elimination of defective and potentially endangered trees, thanks to the valuation of their low value.

The following formula was used:

$$
W R=W P \times G \times L \times K \times P,
$$

where: $W R-$ actual value of a tree $=$ in $z \nmid$

WP - base rate in zł

$G$ - coefficient of species

$\mathrm{P}$ - growth factor

$\mathrm{K}$ - condition factor

$\mathrm{L}$ - location factor

The introduction of the above mentioned factors affecting the value of a tree, enables the estimation of the specific tree, in this case - a poplar, by assessing the value of the species, the condition of viability and growth conditions in a particular location.

The sum of all natural poplar in the alley is 249875,73 zloty. All trees (including 23 specimens), despite different state of health, from bad condition (13 trees) to a very good condition (10 trees), constitute a valuable natural heritage, also in terms of the value to be converted to monetary units. Individual trees were valued from 7195 zloty to 19307 zloty. The alley is a part of the ground the same as the manor house and it requires a special care. It should be remembered that while historic buildings can be restored, it is not possible in case of the trees being described.

\section{Evaluation of the preservation of the alley}

Old trees have high conservation value, but if the alley constitutes the main access to the house- for safety reasons it is required that as many as 13 of them should be removed. Only the trees with deep rotten trunks, large deadwood of branches, numerous hollows, strongly shaken statics, substantial damage of bark or other serious damage (burn inside trunks)were selected to be removed. In case of other trees it is recommended that sanitary cuts in their crowns eliminating excessive occurring of deadwood branches should be made.

Defects in the analysed tree stand have appeared over the years for various reasons. The influence on this situation, had postwar parcelling of land occupied by the manor house and the park. Due to the failure of maintenance works slow degradation of valuable tree stand was observed. There were numerous distortions of the entire 200-metre alley on smaller or larger parts of it. In order to improve and renew the defects of 
plantings, they should be supplemented with at least 20 years old trees of the same species, prepared earlier in a plant nursery of alley trees.

Supplementing of defects, has long been widely used and in case of many tree stands of alleys it enjoys a growing recognition of the restorers.

\section{A Spatial-compositional analysis of the alley as a work of garden art}

Trees growing in a typical double row access alley, constitute the main road to the former property. In order to improve the aesthetics and the level of use of the alley it is necessary to improve the surface between two rows of trees. The most reasonable is to put a layer of crushed stone, which is not significantly different from surfaces used at that time.

\section{Historical analysis of the alley}

The origins of the above alley date back to the sixteenth century. In the seventeenth century, the Baroque garden composition with ponds and geometric utility garden was designed. The next phase of the composition is the eighteenth century, when the Baroque style was combined with the English style - thanks to the opening of a distant view of the ponds in the valley of the river and locating behind it a manor house in Bukowice. At about half of the nineteenth century, the next phase of the development gives rise to the final form of the alley, which remains like that with minor changes until World War II.

In the centre of the complex, around the manor house there are the remains of a regular Baroque garden, and the rest of the park has the characteristics of the English park. In front of the manor house there is a driveway with a flower bed in the shape of the circle. The surface of park paths are paved with granite. To the north of the manor house there are two ponds. To the north-east of the manor house there is located a wooden gazebo. The whole area is fenced and lighted. Getting to a manor house is possible from two sides: the paved road along the stable or along the historical poplar alley, at the beginning of which there is the Christian cross.

The alley was planted in the mid-nineteenth century, when Droblin property was purchased by the Wężyk family, who was also the owner of vast estates - Witulin, Nosów, Wólka Nosowska and Strzyniec villages. In this period there was a further development of the farm and in the place of the old mansion there was built a new brick building existing until present times.

\section{Attachments}

Photographic documentation was performed (Fig. 1 and 2), by supplementing it with recommendations for treatments of tree stand to preserve it in a good condition.

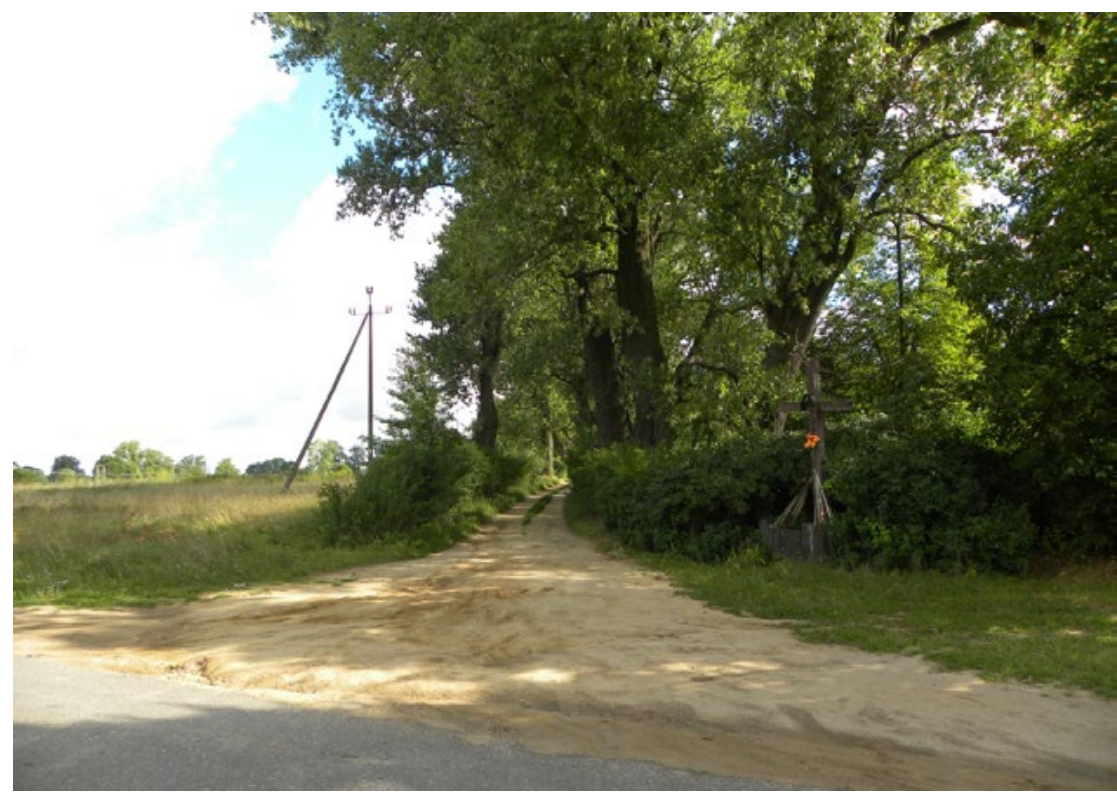

Fig. 1. Poplar alley in Droblin, Leśna Podlaska commune in 2012 - entrance to the park (photo M. Dudkiewicz) 


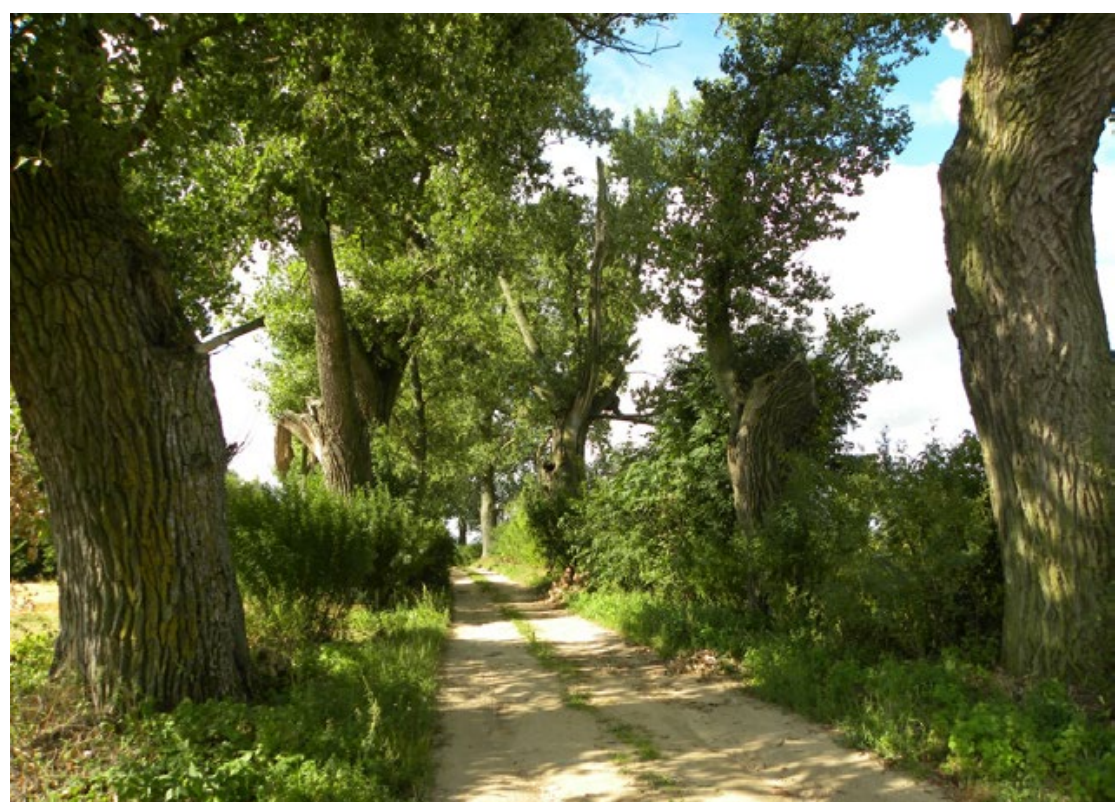

Fig. 2. View of the main alley planted with black poplar (photo M. Dudkiewicz)

\section{Summary}

Poplar alley in Droblin, Leśna Podlaska commune is an important element of the rural landscape. In addition to the historical value it has also biocoenotic value, because it is the place of residence of useful plants and animals. In 2012, during the dendrological inventory combined with the economy of tree stands, there were characterised, evaluated in terms of health and marked 23 black poplars at the age of 150 years. The results of this dendrological study indicate the need for urgent maintenance works in the stand.

\section{References}

[1] Chojnacka M., Wilkaniec A., 2007. Wybrane historyczne obsadzenia przydróżne w krajobrazie wielkopolskiej wsi i miasta [w] Przyroda i miasto t.10, Wyd. SGGW, 133-146.

[2] Kubus M., 2010. Godne prawnej ochrony aleje przydrożne na Pomorzu Zachodnim, część 2. Rocznik Polskiego Towarzystwa Dendrologicznego. Vol. 58 s.71-78.

[3] Lemiechow A., 1905-1906. Obsadzanie dróg. Warunki powodzenia plantacji przyrożnych [w] „Ogrodnik Polski” nr 11, s. 246.

[4] Majdecki L., 1980-1986. Tabela wiekowa drzew. Rkps, Oddział Architektury Krajobrazu SGGW, Warszawa.

[5] Maroszek J., Rogalewska E., 1994. Dwór i rezydencja ziemiańska w krajobrazie kulturowym Podlasia. Wyd. ROS i OŚK w Białymstoku.

[6] Palladio A., 1570. Cztery księgi o architekturze

[7] Płoski A. 2009. Droga i jej otoczenie - świadectwa przemian historycznych na Warmii i Mazurach [w] Aleje przydrożne. Historia, znaczenie, zagrożenie, ochrona. (red.) Worobiec K., Liżewska I. Wyd. Borussia, Olsztyn: 19-23 za Hübner O. [1914]. Der Straßenbaum in der Stadt und auf dem Lande, seine Pflanzung und Pflege sowie die erforderlichen Maßnahmen zu seinem Schutz. Parey. Der Strassenbaum in der Stadt und auf dem Lande, Berlin.

[8] Przesymcka E., Sosnowska M., 2004. Stan zachowania zabytkowego drzewostanu przy drogach Lubelszczyzny [w] Przyroda i miasto t. 8, Wyd. SGGW, 393-404.

[9] Siewniak M., Mitkowska A., 1998. Tezaurus sztuki ogrodowej. Oficyna Wydawnicza Rytm, Warszawa.

[10] Sikora D., 2010. Problematyka zieleni historycznych dróg [w] Materiały z III Konferencji Zieleń Przydrożna, 16-17 września 2010 r. Poznań. 
[11] Szepanowska H., 2009. Metoda wyceny wartości drzew na terenach zurbanizowanych dla warunków Polski, Wyd. Pracownia Poligraficzna Marek\&Piotr, Warszawa.

[12] Szczepanowska H., 2012. Drzewa alejowe - bogactwo kulturowe wsi i miast [w] Aleje podręcznik użytkownika. Wrocław.

[13] Worobiec K., 2009. Wyjątkowy element krajobrazu: aleje przydrożne [w] Aleje przydrożne. Historia, znaczenie, zagrożenie, ochrona. (red.) Worobiec K., Liżewska I. Wyd. Borussia, Olsztyn, s. 19-23. 